\title{
Nursing Education in BiH: Roadmap toward the EU Directive
}

\author{
Mirza Oruč ${ }^{a}$, Dejan Bokonjic ${ }^{b}$, Filip Dumez ${ }^{c}$, Marteen Kaaijk ${ }^{d}$, Lubica Rybarova , Salih Tandir, Adnan Mujezinovic ${ }^{g}$, \\ Duška Jovič ${ }^{h}$
}

\begin{abstract}
$\mathrm{BiH}$ nursing education is still developing toward the $\mathrm{EU}$ directive on regulated professions. At present, there are two large projects dealing with the reform of nursing curricula in Bosnia and Herzegovina; one of them is the Tempus CCNURCA (Competency-based Curriculum Reform in Nursing and Caring in Western Balkan Universities) project and the other is the ProSES (Strengthening Nursing in Bosnia and Herzegovina) project. Both projects have a shared goal to reform nursing curricula and education in general toward the EU directive dealing with regulated professions. This study performed a deep analysis about the current nursing education situation in $\mathrm{BiH}$. The findings were very interesting because there were a lot of different information from different schools, all of which is important to improving nursing education. The methodology used for this research was analytic, comparative, descriptive, and prospective. Three nursing faculties were analyzed: the Faculty of Health in Zenica, the Faculty of Health Sciences in Mostar, and the Nursing Study Program at the University of East Sarajevo. It is important that the Tempus CCNURCA project also be implemented in Albania and Montenegro with EU partners from Belgium, Slovakia, and the Netherlands. Our findings showed important differences between the $\mathrm{BiH}$ and $\mathrm{EU}$ nursing approaches. The number of nursing staff employed, medical orientation of the curricula, practice versus theory, and usage of different teaching and assessment methodologies are some of the major differences between $\mathrm{BiH}$ and $\mathrm{EU}$ approaches in nursing education. These will be the starting and leading points for $\mathrm{BiH}$ nursing schools as they reform and introduce proper nursing education recommended by WHO standards for nursing education and EU directive 2005/13 on regulated professions. In conclusion, a deep analysis of the current situation was a major precondition for the successful improvement of nursing education in $\mathrm{BiH}$ in accordance with $\mathrm{EU}$ standards.
\end{abstract}

Keywords: Nursing $\bullet$ Curricula $・$ Reform $\bullet$ EU directive Education • Bosnia and Herzegovina

a Correspondence

Mirza Oruç, Study Programme Nursing, Faculty of Health, University of Zenica, Zenica Bosnia and Herzegovina. Email: mirza.oruc@gmail.com

b Prof. Dejan Bokonjic, Ph.D., Department of General Medicine and Nursing, Faculty of Medicine, University of East Sarajevo, East Sarajevo, Bosnia and Herzegovina. Email: dbokonjic@gmail.com

c Filip Dumez, Department of Nursing, Odisee, Campus Dirk Martens, Aalst Belgium. Email: filip.dumez@odisee.be

d Marteen Kaaijk, Hanze University of Applied Sciences Groningen, Hanhehogeschool Groningen, Netherlands. Email: m.m.kaaijk@pl.hanze.nl

e Prof. Lubica Rybarova, Ph.D., Department of Nursing, Faculty of Health Sciences, Prešov, Slovakia. Email: lubica. rybarova@unipo.sk

f Salih Tandir, Study Programme Nursing, Faculty of Health, University of Zenica, Zenica Bosnia and Herzegovina. Email: a.mujezinovic@hotmail.com

g Adnan Mujezinović, Study Programme Nursing, Faculty of Health, University of Zenica, Zenica Bosnia and Herzegovina. Email: tandirsa@yahoo.co.uk

h Duška Jović, Study Programme Nursing, Faculty of Health Sciences, University of Banja Luka, Banja Luka, Bosnia and Herzegovina. Email: jovicduska@yahoo.com 
Nursing education in Bosnia and Herzegovina has evolved rapidly in the last decade. Its transition from traditional to modern, $\mathrm{WHO}$ and $\mathrm{EU}$ directive regulated, nursing education remains ongoing. The process of transformation and implementation of $\mathrm{WHO}$ and $\mathrm{EU}$ directive recommendations is quite slow; nevertheless, it is continuous because of the complex political constitution of $\mathrm{BiH}$; which, in turn, leads to the complex constitution of the educational and health care systems. Bosnia and Herzegovina consists of two entities (Federation of Bosnia and Herzegovina and Republic of Srpska) and one district (Brčko District).

The Federation of Bosnia and Herzegovina consists of 10 cantons, each of which has its own Ministry of Education and Health Care, which oversees the education of professional health care staff/professionals. In addition to each canton's Ministry of Education, there is also a Ministry of Education, Science, and Culture and a Ministry of Health at the federal level. In the Republic of Srpska (RS), meanwhile, there are just two ministries that are responsible for the education of health care professionals (the Ministry of Education and the Ministry of Health). Finally, the Brčko District has its own constitution with relevant legislative bodies.

The system of education in $\mathrm{BiH}$ is quite similar to the organization of the health care system. In the Federation of Bosnia and Herzegovina, the coordination role is provided to the Federal Ministry of Education and Science, while full responsibility is provided to the cantonal ministries responsible for education in each canton.

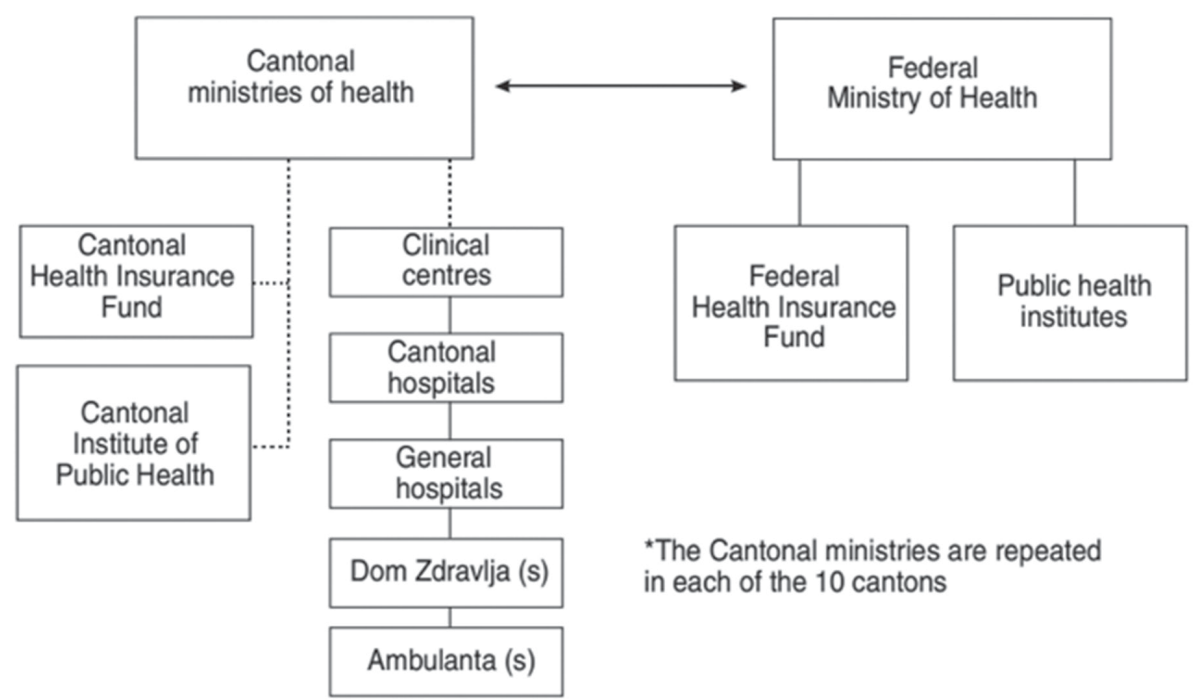

Figure 1: Organizational structure of the health care system in the Federation of $\mathrm{BiH}$ (Cain, Duran, Fortis, \& Jakubowski, 2002). 
At present, in Bosnia and Herzegovina, there are 10 public higher education institutions ( 8 universities and 2 colleges) and 37 private higher education institutions. Based on this information, there are currently 8 public nursing faculties/schools (Centre for Information and Recognition of Qualifications in Higher Education, 2014), as presented in Table 1 below.

\begin{tabular}{lcc}
\hline Table 1 & & \\
Review of Public Nursing Faculties/Schools in BiH (Avdic, Jovic, \& Dropic, 2013) & \\
\hline Faculty & Length of education & ECTS credits \\
\hline University of Sarajevo-Faculty of Health Sciences & 4 years & 240 ECTS \\
University of Tuzla-School Nurses & 4 years & 240 \\
University of Zenica-Faculty of Health & 3 years & 180 \\
University of Mostar-Faculty of Health Sciences & 3 years & 180 \\
University of Bihac-Faculty of Health & 3 years & 180 \\
University of Banja Luka Faculty of Medicine-Health Care Study & 4 years & 240 \\
Program & & \\
University of East Sarajevo-Faculty of Medicine-Nursing Study & 3 years & 180 \\
Program & & \\
School for Nurses Prijedor & 4 years & 240 \\
\hline
\end{tabular}

Nursing curricula and nursing programs are mainly based on traditional education methods with a slow transition toward the EU directive's recommendations. The Tempus Competency-based Curriculum Reform in Nursing and Caring in Western Balkan Universities (CCNURCA) project was approved in 2013 by the EU Commission to help with this transition process not just in Bosnia and Herzegovina but throughout the entire Western Balkan (WB) region.

The overall aim of the project was the curricular reform of higher nursing education to align it with the competency-based educational and professional standards that have been defined by all European Union member states. In this manner, this proposal fully supports the ongoing reform of higher education in the WB region.
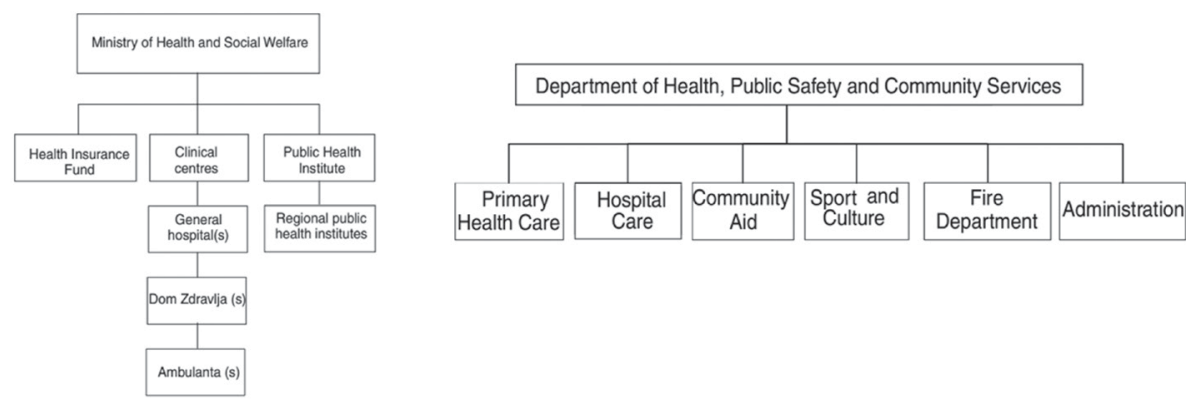

Figure 2: Organizational structure of the health care system in RS (left) and the Brčko District (right) (Cain et al., 2002). 
Nursing education at the university level has long been established in $\mathrm{BiH}$, but it was regulated at the domestic level, and compliance with EU and WHO directives was not fully implemented. Changes toward implementation of these directives and recommendations are sorely needed in university-level nursing education throughout the $\mathrm{WB}$ region, including $\mathrm{BiH}$. Based on $\mathrm{WHO}$ standards.

\section{Method}

The methodology used for this research was analytic, comparative, descriptive, and prospective. The study analyzed nursing faculties: the Faculty of Health in Zenica, the Faculty of Health Sciences in Mostar, and the Nursing Study Program at the University of East Sarajevo. It is also important that the Tempus CCNURCA Project begin operations in Albania and Montenegro with the assistance of EU partners from Belgium, Slovakia, and the Netherlands.

Nurses and midwives are important workforce for delivering health care

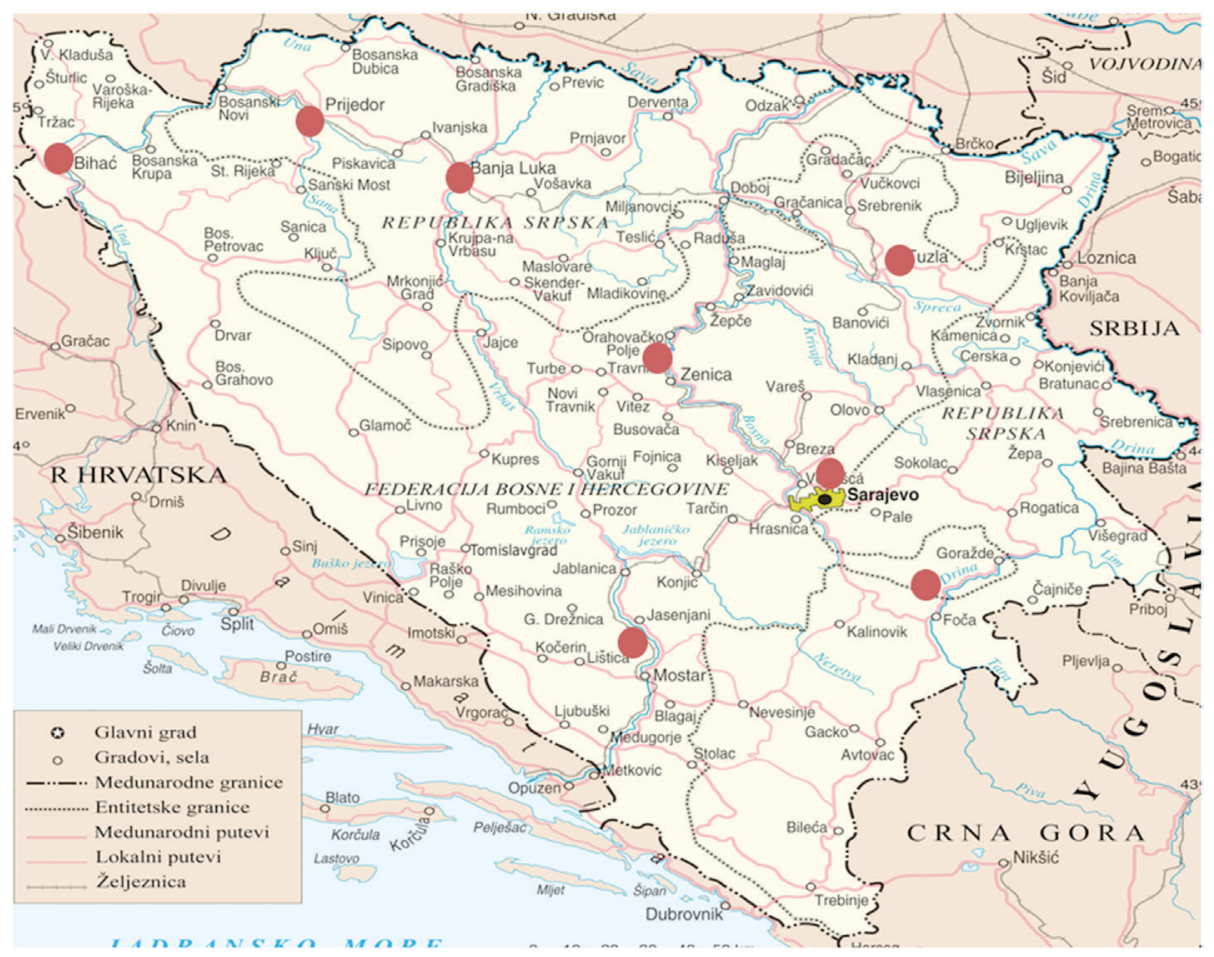

Figure 3: Geographical position of public nursing schools in Bosnia and Herzegovina. 
services, especially at primary care level. Therefore, level of education for health staff required for nursing practice is a bachelor's degree for many complex skills; however, because of the complex organizational system, different levels of nursing education still exist in $\mathrm{BiH}$ (Figure 4).

After analyzing the current situation in $\mathrm{BiH}$ and other $\mathrm{WB}$ countries, we discovered the most important parts of the educational and health care system that should be improved are equalizing differences in basic nursing education, upgrading the training and educational process, establishing a continual education process, and improving employability of nurses. Each of these issues can be discussed as separate topics, but it is necessary to identify them to develop an easier solution.

Programs should include $4600 \mathrm{~h}$ of education with $50 \%$ of time spent in practical training, but most of the programs are below this number of hours. One of the main goals of the Tempus CCNURCA project is to develop and implement curricula to achieve these requirements.

By law, in the Federation of $\mathrm{BiH}$, the specialization of nurses is regulated by articles 24, 25, 26, 27, and 28 (Official Gazette of Federation of Bosnia and Herzegovina, 2013). However, there is presently no official specialization training in $\mathrm{BiH}$. There are an increasing number of health care professionals that have completed the Faculty of Health Sciences curriculum with a total involvement of $1.5 \%$ of all health professionals nationwide (Federacija Bosne i Hercegovine Federalno Ministarstvo Zdravstva, 2012).

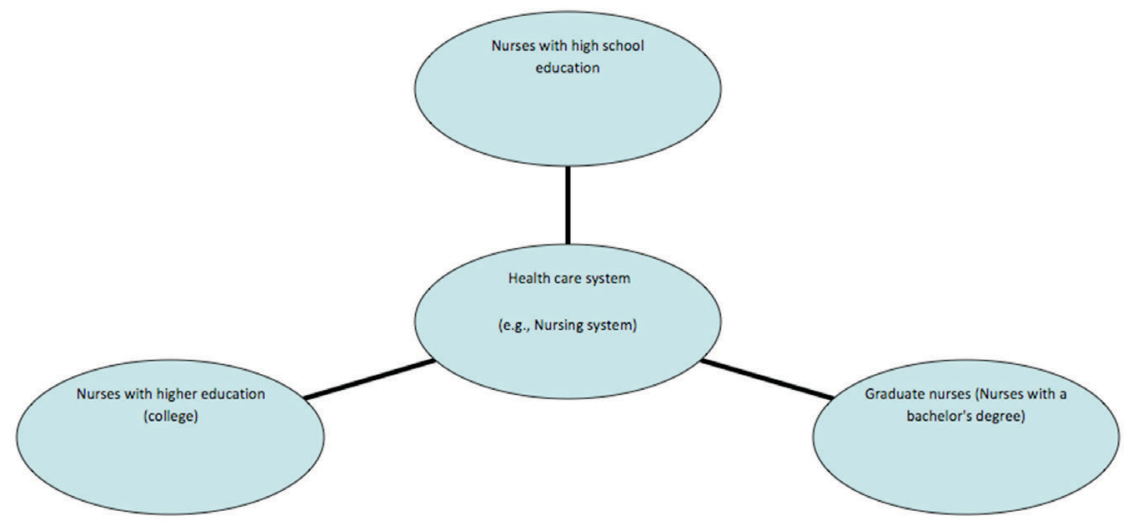

Figure 4: Different level of nursing education, divided by education level, in the $\mathrm{BiH}$ health system. 


\begin{tabular}{cccccc}
\hline Nurses FBiH & University Degree M + F & College & High School & Total & Ratio Nurses/10,000 people \\
\hline Year 2013 & $56+201$ & $131+710$ & $1587+7468$ & 10153 & 1.01 \\
Year 2012 $^{2}$ & $49+197$ & $112+684$ & $1520+7435$ & 9997 & 0.99 \\
Year 2011 & $22+118$ & $115+697$ & $1462+7371$ & 9785 & 0.9785 \\
Year 2010 & $21+78$ & $125+716$ & $1475+7310$ & 9725 & 0.9725 \\
\hline
\end{tabular}

\begin{tabular}{cccccc}
\hline Nurses RS & University Degree M + F & College & High School & Total $^{5}$ & Ratio Nurses/10,000 people \\
\hline Year 2013 & N/A & 426 & 4433 & 4859 & 0.485 \\
Year 2012 & N/A & 417 & $3984+397+97$ & 4478 & 0.44 \\
Year 2011 & N/A & 415 & $3908+390+105$ & 4818 & 0.48 \\
Year 2010 & N/A & 409 & $3828+395+105$ & 4737 & 0.47 \\
\hline
\end{tabular}

The most important thing is that all of the abovementioned problems are identified. This will help $\mathrm{BiH}$ universities progress toward implementing new methodologies and introducing modern recommendations and trends in nursing education. Implementation of projects, such as CCNURCA, PROSES, and other Twinning projects and national projects are proof that universities, faculties, and nursing schools are ready and willing to implement EU directives as well as WHO recommendations and standards.

\section{Results}

Our detailed analysis showed us that the current $\mathrm{BiH}$ nursing education system is complicated. There are many differences between nursing schools in $\mathrm{BiH}$, such as the ratio of practical and theoretical number of hours, usage of different teaching methodologies, and orientation of curricula toward EU directive 2005/13 on regulated professions.

Regarding our findings on the Tempus CCNURCA project in the Western Balkan countries, in participating institutions, we can see that most nursing schools have a different ratio of theoretical and practical number of hours. Each nursing school/faculty has a 3-year education, but none of them provide the $4600 \mathrm{~h}$ of education required by the directive. All three faculties from $\mathrm{BiH}$ (Mostar, East Sarajevo, and Zenica) need to reform their curricula to complete alignment with the regulations of the $\mathrm{EU}$ directive.

The current legal framework for health professions (regarding nursing) is based on three main laws: 1) the Law on Health Care, published in the Official 
Gazette of the Federation of $\mathrm{BiH}(\mathrm{FBiH})$ No. 46/10; 2) the Law on Nursing and Midwifery found in the Official Gazette of the Federation of BiH No. 43/13; and 3) the Law on Health Care, Official Gazette of the Republic of Srpska No.106, 2009. It is very important to mention that the Law on Nursing in the Federation of Bosnia and Herzegovina covers many professional and educational concerns regarding nursing.

Along with these laws, nursing education is regulated by the Law on Education, which is a cantonal-level statute in the $\mathrm{FBiH}$ and a republic-level law in the RS. Nursing programs and degrees are very similar on every institution.

In the $\mathrm{BiH}$ health care system, nurses represent the main and largest category of the workforce and play a major role, at least in numbers, in providing health care. It includes nurses on all educational levels, including those with a high school, college, or university degree. $\mathrm{BiH}$ still does not have an established national register of nurses. By the $\mathrm{FBiH}$ law, a professional association of nurses can be organized on the Cantonal level. Last year, the Federal Association of Graduate Nurses was established and formed. They developed action plans and a road map with the goal of developing a nurse register, at least in the Federation of Bosnia and Herzegovina.

Based upon the number of nurses involved in the health care system in $\mathrm{BiH}$, we can conclude that a large number of nurses are involved in this process. In a 2011 report conducted in the Federation of Bosnia and Herzegovina alone, among all health care system employees, there were 12,557 nurses (53.7/10,000 residents, OECD $97.2 / 10,000$ population). Total number of employees in the health care system was 28,940 , out of which $43.3 \%$ were nurses. Out of the total employees in all medical institutions in $\mathrm{FBiH}$ on the primary, secondary, and tertiary levels in 2011, nurses comprised more than $2 / 3$ of the total number of employees; those from different educational backgrounds and orientations totaled more than $70.4 \%$. According the data from the Institute for Public Health in $\mathrm{FBiH}$, most nurses (48.7\%) have a high school education and just 1.0\% graduated from a high medical school or faculty.

Out of total number of health care employees in RS $(13,040), 6,491$ of them are Nurses; 410 (6.3\%) of them have a university degree, while 3,908 (60.2\%) have a high school education. 


\section{Conclusion}

Nurses represent the largest percentage of the health care workforce in Bosnia and Herzegovina. In the field of nursing, the educational system is still divided into two levels with no proper distinction in legal documents regarding what is the responsibility of nurses with a high school education and what is the responsibility of nurses with a bachelor's degree.

When we review the number of nurses in both the Federation of Bosnia and Herzegovina and the Republic of Srpska, we can see there is a big need for additional, properly educated, staff to be employed. The average number of nurses per 10,000 people in OECD is approximately 8.4, while during the past five years in $\mathrm{BiH}$, this figure has not exceeded 2.0 per 10,000. BiH's nursing education system is characterized by the following:

- Teaching methodology varies from school to school.

- There is an urgent need for definition of competencies and learning outcomes in the field of nursing at a state level.

- Implementation of new teaching methodologies and assessment methodologies is crucial.

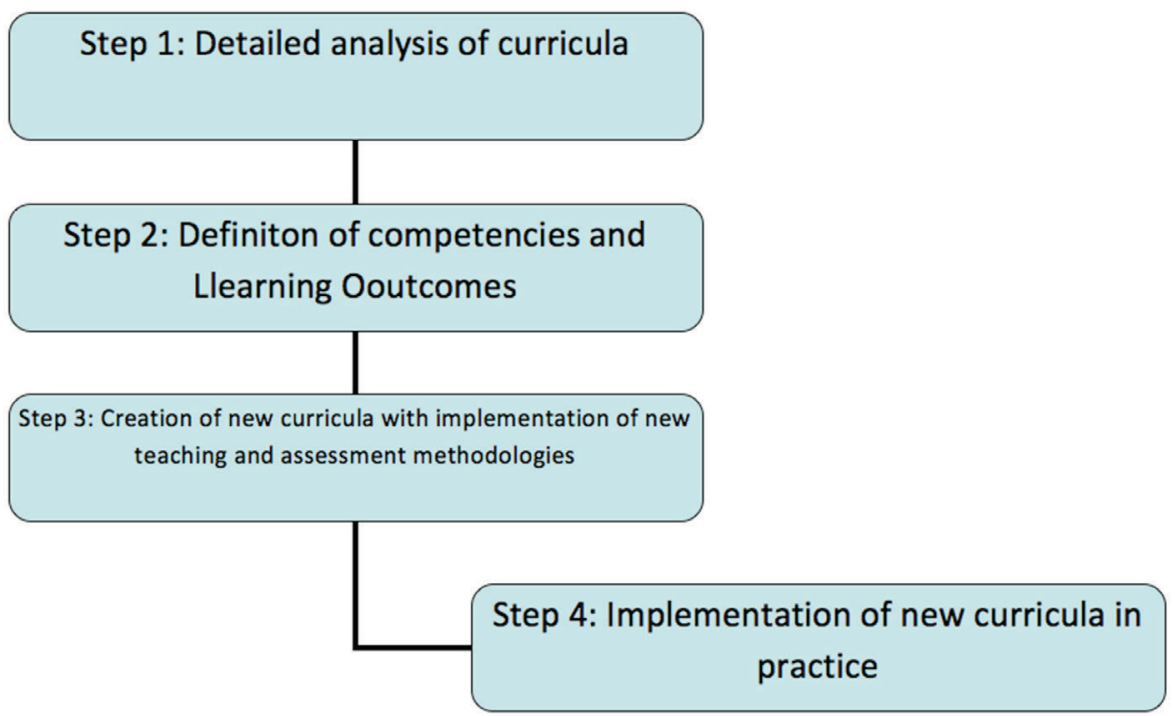

Figure 5: Steps that should be taken to accomplish implementation of the EU directive and regulations for nurses. 
- Curricula reform toward alignment with the recommendations of EU Directive 2005/13 is needed.

- More nurses urgently need to become involved in the education process.

- Curricular reform is needed toward a holistic rather than a doctoral approach.

- Steps that should be taken to accomplish implementation of the EU directive and regulations for nurses are as follows (Figure 5).

\section{References}

Cain, J., Duran, A., Fortis, A., \& Jakubowski, E. (2002). Heath care systems in transition: Bosnia and Herzegovina. Copenhagen: European Observatory on Health Care Systems. Retrieved from http://www.euro.who.int/_data/assets/pdf_file/0018/75132/E78673.pdf

Centre for Information and Recognition of Qualifications in Higher Education. (2014). Information about higher education institutions. Retrieved February 25, 2015 from http://www.cip.gov.ba/index.php/bs/2014-01-21-22-32-01

Avdić, M., Jović, D., \& Dropić, E. (2013). Greet van Malderen, Rene Schrwendimann, Formalno visokoobrazovanje medicinskih sestara u BiH, I Naučno stručna konferencija Sestrinstvo Jučer, danas i Sutra Zenica Novembar 2013 (ProSes Projekat Jačanja sestrinstva u BiH, FAMI Fondacija).

Official Gazette of Federation of Bosnia and Herzegovina. (2013). No 43. 05.06.2013, pp. 18-35. Retrieved from http://www.fmoh.gov.ba/images/federalno_ministarstvo_ zdravstva/zakoni_i_strategije/zakoni/zakoni_PDF/Zakon_o_sestrinstvu_i_ primaljstvu_43_13.pdf

Federacija Bosne i Hercegovine Federalno Ministarstvo Zdravstva. (2012). Population health care and health condition in Federation of Bosni anad Herzegovina in 2012. http://www.fmoh.gov.ba/images/federalno_ministarstvo_zdravstva/preporucujemo/ istrazivanja/dokumenti/zdravstveno_stanje_2012.pdf

Institute of Public Health of Federation of Bosnia and Herzegovina. (2013). Health statistics annual Federation of Bosnia and Herzegovina, 2013 (Year XII, No XII). Sarajevo: Author.

Institute of Public Health of Federation of Bosnia and Herzegovina. (2012). Health statistics annual Federation of Bosnia and Herzegovina, 2012 (Year XI, No XI). Sarajevo: Author. 
Institute of Public Health of Federation of Bosnia and Herzegovina. (2011). Health statistics annual Federation of Bosnia and Herzegovina, 2012 (Year X, No X). Sarajevo: Author.

Institute of Public Health of Federation of Bosnia and Herzegovina.(2001). Health statistics annual Federation of Bosnia and Herzegovina, 2012 (Year IX, No IX). Sarajevo: Author.

Public Institute, Republic of Srpska. (2013). Analysis of Population Health in Republic of Srpska. Banja Luka: Author.

Public Institute, Republic of Srpska. (2012). Analysis of Population Health in Republic of Srpska. Banja Luka: Author.

Public Institute, Republic of Srpska. (2011). Analysis of Population Health in Republic of Srpska. Banja Luka: Author.

Public Institute, Republic of Srpska. (2010). Analysis of Population Health in Republic of Srpska. Banja Luka: Author.

\section{(Footnotes)}

1 Institute of Public Health of Federation of Bosnia and Herzegovina, 2013.

2 Institute of Public Health of Federation of Bosnia and Herzegovina, 2012.

3 Institute of Public Health of Federation of Bosnia and Herzegovina, 2011.

4 Institute of Public Health of Federation of Bosnia and Herzegovina, 2001.

5 General nurses, midwives, and pediatric nurses.

6 Public Institute, Republic of Srpska, 2013.

7 Public Institute, Republic of Srpska, 2012.

8 Public Institute, Republic of Srpska, 2011.

9 Public Institute, Republic of Srpska, 2010. 